\title{
Foreword
}

W elcome to the second edition of the Journal for 2004.

\section{The E dinburgh 2004 conference:}

The continuing success of the Journal was reflected in the continuing success of the Journal's international clinical conferences. The second of these was held in Edinburgh in the Summer of 2004 and attracted del egates from across the world, with papers from jurisdictions as diverse as the $\mathrm{U}$ nited States and U ganda, South A frica and the South Pacific. The broad theme of the conference - Who benefits from clinic? - was broad enough to encompass wideranging reviews of the development of the clinical method in legal training and of the development of a Best Practice models for clinic, alongside more narrowly focused papers on the development of clinical representation at housing representation schemes, and the particular issues of sustainability in setting up clinics in law schools.

\section{This edition of the Journal:}

This edition of the Journal draws on both this year's conference and on last years' - with Roy Stuckey's masterful review of the development of legal education in the US and the UK, and its consequent impact on the development of clinic; with Hugh Brayne and A drian Evans' paper on the development of a Q uality-lite model for clinics; and with Liz Curran's paper from the previous year's London conference looking at the development of law reform work within one A ustralian clinic. A longside these papers, readers will also find food for thought in Ross $\mathrm{H}$ yam's review of the potential for case management and assessment software to be used within law clinics as an integral part of the clinical process. Finally, in the student review section, there is a short article from $\mathrm{M}$ artin Wilson, a N orthumbria U niversity student, who was in the enviable position of having won the first Irwin M itchell International Clinical Scholarship, a generous $f 1000$ award which funded $M$ artin to spend a month during the Summer of 2004 attending the Springvale law clinic at $M$ onash $U$ niversity, enabling $M$ artin to reflect on the student experience at two different types of clinic in two different legal jurisdictions. His paper is a valuable reminder to all who work in clinic of how much we can all learn from one another.

\section{Change of Editor:}

This is the first edition of the Journal where I have taken the helm as Editor. I could not be more fortunate in my predecessor, Cath Sylvester, who will be known to many of the readers of the Journal. Cath was the founder editor of the Journal, customarily a thankless task - but one which she carried out to the highest standard. The success of the Journal has been due to her hard work over the first years of the Journal's publication, and to the support of the impressive editorial board which she put together. I know that I will be reliant on that work and on her continuing advice and support in the production of these future editions of the Journal. 


\section{The 2005 IJCLE conference - Melbourne, 13-15th July 2005}

Building on the huge success of the London and Edinburgh conferences in 2003 and 2004, the 2005 conference is to be held in conjunction with the 8th Australian clinical legal education conference in M elbourne, Victoria, Australia.

The title of the conference is: Flowers in the D esert: C linical L egal E ducation, Ethical A wareness and C ommunity Service and the conference will bring to gether justice educators, clinical legal educators, NGO s, community legal centres, legal aid lawyers and legal ethicists from both hemispheres, with the objective of expanding the impact of clinical legal education, operating in a multi-disciplinary ethical framework, in the reinvigoration of legal education, justice education and client service Specific themes for the conference will include the clinical-ethics interface, clinical sustainability, specialist clinics, political pressure on clinical programs, justice clinics, clinics as Trojan horses in legal education, the clinical IT environment, innovation and evaluation.

The conference dates are 13 - 15 July 2005, and the conference will take place at the Novotel, St Kilda, M elbourne. The registration fee will be \$AU 330 for payment by 31st M arch 2005, \$AU 420 thereafter. Full information will be distributed in January-February 2005. In the meantime, enquiries from those who are interested in submitting papers or in attending, are welcomed by the Conference Co-Convenors: A drian Evans, M onash (adrian.evans@law.monash.edu.au) and Philip Plowden, Northumbria U niversity (philip.plowden@ northumbria.ac.uk).

We look forward to seeing you there!

Philip Plowden

Editor 